\title{
Graduate university aimed at research flexibility
}

Tokyo

A UNIQUE new graduate university is to be formed under the terms of a bill passed last week by the lower house of the Japanese Diet. The university, which will offer doctoral courses to scientists with masters' degrees, will introduce some flexibility to Japan's rigid university research system, increase the competition for graduate students and perhaps help to open the country to foreign scientists.

The idea of creating the "General Research Graduate University" was first officially put forward in 1982 by the directors-general of the national research institutes, mostly established in the 1970s as central facilities for use by the universities.

Although among the best-equipped research institutes in Japan, the institutes have not been free to enrol their own graduate students or to award degrees. Graduate students wishing to use an institute's facilities have instead been sent by outside university professors.

The new graduate university, to be jointly administered by the research institutes, will provide a supply of graduate students and award doctoral degrees. It will open in October, initially on a temporary site on the a campus of the Tokyo Institute of Technology in Yokohama. The first 50 students will be accepted next April and dispersed to the participant research institutes - those already cited plus the institutes of genetics (Shizuoka) and statistical mathematics (Tokyo). There will be three departments to begin with (in physical, life and cultural science), but the organizers also hope to add a joint research department for interdisciplinary research.

Students with masters' degrees will be accepted from universities throughout Japan, but Professor Saburo Nagakura, president of the Okazaki National Research Institutes, who is in charge of setting up the university, is particularly keen to accept foreign graduate students; he has already discussed the possibility of student exchange with a British university.

Nagakura hopes that the new graduate university will also introduce some flexibility imto a system in which lateral movements of students, teachers and researchers is notoriously small.

But some of the national laboratories have decided not to join the new network, continuing instead to recruit graduate students from their mother universities (in these cases, Tokyo University).

Indeed, Tokyo University has plans to strengthen its graduate research programme by fusing the undergraduate and graduate schools, offering a six-year master's course. But this proposal is opposed by some of the university's research institutes, which regard it as an attempt to 'steal' their graduate students (see Nature 330, 597; 1987).

Behind all these moves lies a battle among Japan's professors to gain access to outstanding graduate students. But
Nagakura says that the new graduate university is not intended to develop into a 'tug of war' over graduate students, a view echoed by Professor Akito Arima, vicepresident of Tokyo University, who is promoting the university's graduate school reform.

With an intake of only 50 students a year, the new graduate university will have a student population of only 150 200 , so that there will be plenty of students for everyone, Nagakura says.

David Swinbanks

\section{US plan for the protection of African elephants}

\section{Washington}

To reduce the slaughter of African elephants for their ivory, the US-based African Wildlife Foundation (AWF) last week called for people to stop buying worked ivory jewellery and other products. Short of a complete ban on ivory imports, AWF considers a US consumer-embargo the most effective means to cut down on the illegal poaching of African elephants.

AWF associate Cynthia Moss says poaching has cut the African elephant population by half since 1979 , and adds that each year 80,000 elephants die to support the demand for worked ivory 70,000 directly for their tusks and another 10,000 young elephants after their mothers or herd leaders have been killed.

The United States supports one-third of the world's demand for worked ivory, and an estimated 80 per cent of the ivory sold here is obtained illegally. The Convention on the International Trade in Endangered Species (CITES) lists the African elephant as a threatened species. But no effort is made to control the trade of worked ivory because its origins are so difficult to trace.

Some non-CITES African countries without elephant populations, such as Burundi, are said to buy poached ivory for export. Other African governments do nothing to control the illegal ivory trade going on within their borders.

Moves are afoot in the United States to crack down on the illegal ivory trade. Last month the US Fish and Wildlife Service banned the import of all ivory from Burundi. Legislation has also been introduced to ban the import of all elephant products to the United States.

But most wildlife conservation organizations and ivory trade experts support a combination of reducing the demand for ivory products and tighter control of ivory imports to slow down the poaching of elephants. Many fear that a strict ban on imports would simply force the illegal ivory trade further underground, and prevent African countries from tapping one of their most important national resources once the elephant populations recover.

The US House of Representatives Committee on Merchant Marine and Fisheries is putting together legislation that may offer an alternative. The draft proposes a five-year moratorium on imports from only those African countries unable to control their ivory trade. There would also be a US tax on sales of ivory products to be channelled into an African Wildlife Conservation Fund. The draft would further ban imports of worked ivory from countries or other intermediaries purchasing ivory from countries that encourage poaching. 